\title{
Peanut (Arachis hypogaea) Production as Influenced by Various Row and Hill Spacings
}

\author{
Reybhoy A. Ramos \\ Department of Plant Science, College of Agriculture, Mindanao State University- Buug Campus \\ Bliss, Buug, Zamboanga Sibugay, 7009
}

\begin{abstract}
The study was conducted to determine the yield of peanut as affected by different row and hill spacings. The experiment was done under the soil and climatic requirements of Zamboanga Sibugay, Philippines with an average temperature of $27.3^{\circ} \mathrm{C}$. The experiment was laid using Randomized Complete Block Design (RCBD) with sixteen combined treatments. An area of 80 square meters was divided into 16 plots, each plots measured $1 \mathrm{~m}$ by $5 \mathrm{~m}$ excluding canals. There were two factors used in the study, the different rows and hill spacings. The row spacing used were $R_{1}$ (12 inches), $R_{2}$ (16 inches), $R_{3}$ (20 inches), $R_{4}$ (24 inches) and the hill spacing used were $\mathrm{H}_{1}$ (6 inches), $\mathrm{H}_{2}$ (7 inches), $\mathrm{H}_{3}$ (8 inches), $\mathrm{H}_{4}$ (9 inches). Complete fertilizer was drilled at the base of the plant 30 days after planting at the rate of 1.83 grams per hill. Tobacco spray was applied twice, first at 15 DAP and second at 50 DAP and kakawate spray was applied 43 days from planting to prevent and repel insect pest. Result revealed that the average number of pods per plant per plot, average weight of pods in gram per plant per plot, total number of pods per plot, and total weight of pods in kilogram per plot had no significant difference as affected by different row and hill spacings. However, the result on the average number of seeds per plant per plot showed that there is a significant difference among treatments. Statistical analysis revealed that the computed " $f_{1}$ " is greater than the tabulated " $f_{1}$ " at $5 \%$ level of significance.
\end{abstract}

Keywords:- Peanut; Randomized Complete Block Design (RCBD); Row Spacings; Hill Spacings; Complete Fertilizers; Days After Planting (DAP).

\section{INTRODUCTION}

In the Philippine, the volume of agricuture food production has emerged as a problem due to the continous growing population and economic status of the realm. Farmers are identified as the main actor to unravel this difficulty. In addition, Agricultural Extension Workers (AEWs) play an important role in this issue. However, limited studies had been made comparing rows and spacings of peanut in the locality. Thus, there is a need to estblish a demo farm showing the effectivity of different rows and spacings between and among crops.

Peanut as a crop often grown during summer is planted after some major winter crops in the rotation. Peanut may be grown early or late according to the harvest time of preceding crop. [5] reported that, number of pods, as well as, weight of pods and seeds per plant were decreased with late sowing dates. In addition, [3] and [22] pointed out the same result and cleared that delaying planting dates decreased peanut yields of seeds and oil per faddan. [2] determined that, the values of quality characteristics of peanut pods, seed index, shelling percentage and seed oil percentage were increased with early sowing dates.

Peanut is one of the world's most popular crops cultivated in tropical and sub-tropical regions. It is rich in protein, oil, fatty acid, carbohydrates, vitamins and minerals contents. It contains $45-55 \%$ oil, $20-25 \%$ protein, 16-18\% carbohydrate and 5\% minerals [12]-[13]. [8], pointed out that to define the relationship between row spacing, plant densities and yield; two approaches are used commonly. First, if the plant produces enough leaf area to maximize isolation interception during reproductive growth, maximum yield can be obtained. Secondly, equidistant row spacing between plants will provide maximum yield since it will minimize inter plant competition. [6] indicated that as the number of plants per unit area increased, competition for growth resources such as nutrients, water and light also increased. Crop yield is determined by the efficiency with which plant population uses available environmental resources for growth. According to [25], peanut (Arachis hypogaea L.) cultivars vary in the duration of plant growth and maturity, growth habits, and branching patterns that range from the erect and sequential types of Arachis hypogaea subsp. fastigiata to the semi-erect and runner types with alternated branching in Arachis hypogaea subsp. hypogaea. The manipulation of row spacing dimensions, plant populations and the overall special arrangement of crop plants in a field has been the subject of considerable discussion among farmers and agronomists for many years. Plant density is important factor for growth and pod production rate, pod and kernel yield in peanut [25].

[17] pinpointed that the effect of row spacings on seed and pod yields was significant and $50 \mathrm{~cm}$ row spacing revealed higher yields, compared to $60 \mathrm{~cm}$ row spacing. Similarly, [19], proposed that maximum yield was obtained with 7-8 plantsm $^{-2}$ and yield gradually increased to maximum with 11-14 plantsm $^{-2}$. Yield was unaffected by further increasing plant density while at lower than 7-8 plantsm $^{-2}$ it was significantly reduced. [21], pointed out that pod yield of peanut was increased with increasing of plant density from 3.0-8.3 plantsm $^{-2}$ but increasing plant density to 14.8 plants $\mathrm{m}^{-2}$ pod yield decreased. [9] concluded that number and weight of pods per plant increased with 
ISSN No:-2456-2165

increasing hill-spacing, while [10] and [24] revealed that increasing hill-spacing increased pod and seed index, shelling percentage, seed oil percentage, seed and oil yields per faddan.

[14], [23] and [26] pointed out that delaying harvesting time increased seed oil percentage, seed and oil yields per faddan. Recommendations for optimum row spacing and sowing rate for lucerne seed production vary in the literature [4], and several studies have reported conflicting results [20] [15] [16]. In New Zealand, lucerne seed has commonly been produced in rows 9 or $18 \mathrm{~cm}$ apart at sowing rates of 6-12 $\mathrm{kg} / \mathrm{ha}$ [27]. However, [7] recommended a sowing rate of $1 \mathrm{~kg} / \mathrm{ha}$ and row spacing of $75 \mathrm{~cm}$, although they produced no evidence to support these recommendations. Experiments conducted overseas, especially in the United States, have shown that high seed yields were obtained from lucerne sown at rates ranging from 0.5 to $2 \mathrm{~kg} / \mathrm{ha}$ and in rows from 60 to $150 \mathrm{~cm}$ apart [1], [11].

In this study, the average number of pods per plant per plot, average weight of pods in grams per plant per plot, average number of seeds per plant per plot, total number of pods per plot, and total weight of pods in kilogram per plot were determined.

\section{MATERIALS AND METHODS}

The equipment used in the study are the following: carabao drawn plow, bolo, trowel, sprayer, signboard, meter stick, tape measure, markers, scissors, plastic container, plastic straw, calculator, ballpen, and record book. NSIC Pn15 is a newly registered peanut variety used in this study from ICRISAT in India. The seed matures 120 days from planting and has an average height of $87 \mathrm{~cm}$. The seed color is brown orange and weighs 81 grams per 100 seeds. It yields $2,775 \mathrm{~kg}$ per hectare during wet season and $1,430 \mathrm{~kg}$ per hectare during dry season. This peanut variety from India is also resistant to wilting and other foliar diseases such as Cercospora leaf spot and Rust. The fertilizer applied in the study was complete fertilizer (14-14-14).

The study used organic pesticides such as Tobacco Spray and Kakawate Spray to prevent and repel insects' infestation. A land area of $80 \mathrm{~m}^{2}$ was thoroughly prepared by cutting all grasses and putting them away from the experimental area. After clearing the area, it was plowed and harrowed two times with an interval of seven days. The field was equally divided into 16 plots having a dimension of 1-meter-wide and 5 meters long, excluding canals which served as drainage. Two factors were considered in this study: the different rows and hill spacing. There were sixteen combined treatments. The treatments were the following:

\begin{tabular}{|c|c|c|}
\hline \multirow{2}{*}{ Treatments } & \multicolumn{2}{|c|}{ Description } \\
\cline { 2 - 3 } $\mathbf{T}_{\mathbf{1}}$ & Row (inches) & Hill (inches) \\
\hline $\mathbf{T}_{\mathbf{2}}$ & 12 inches & 6 inches \\
\hline $\mathbf{T}_{\mathbf{3}}$ & 12 inches & 7 inches \\
\hline $\mathbf{T}_{\mathbf{4}}$ & 12 inches & 9 inches \\
\hline $\mathbf{T}_{\mathbf{5}}$ & 16 inches & 6 inches \\
\hline $\mathbf{T}_{\mathbf{6}}$ & 16 inches & 7 inches \\
\hline $\mathbf{T}_{\mathbf{7}}$ & 16 inches & 8 inches \\
\hline $\mathbf{T}_{\mathbf{8}}$ & 16 inches & 9 inches \\
\hline $\mathbf{T}_{\mathbf{9}}$ & 20 inches & 6 inches \\
\hline $\mathbf{T}_{\mathbf{1 0}}$ & 20 inches & 7 inches \\
\hline $\mathbf{T}_{\mathbf{1 1}}$ & 20 inches & 8 inches \\
\hline $\mathbf{T}_{\mathbf{1 2}}$ & 20 inches & 9 inches \\
\hline $\mathbf{T}_{\mathbf{1 3}}$ & 24 inches & 6 inches \\
\hline $\mathbf{T}_{\mathbf{1 4}}$ & 24 inches & 7 inches \\
\hline $\mathbf{T}_{\mathbf{1 5}}$ & 24 inches & 8 inches \\
\hline $\mathbf{T}_{\mathbf{1 6}}$ & 24 inches & 9 inches \\
\hline
\end{tabular}

Treatment $(T)$

The experimental design was laid out using Randomized Complete Block Design (RCBD). Random numbers were generated from the calculator. This was used to distribute the treatments to each plot by ranking them from the lowest to the highest. Planting was done after the area was thoroughly prepared. Three seeds of peanut per hill were sown directly to the ground with different row and hill spacing. These were covered with a thin fine soil. Thinning was done 7 days after germination leaving only one plant per hill. Peanut plants were watered regularly using sprinkler every morning until the plants begin to flower. Hilling-up was done thrice. This was to provide better drainage and more room for peanut pods to grow. Weeding started when weeds began to compete with the crops. This was done with the use of trowel and was followed by shallow cultivation close to the base of each plant to control weeds and give enough room for the development of pods.

Complete fertilizer at a rate of 1.83 grams per hill was drilled 30 days after planting at the base of the plant and covered with a thin layer of fine soil about three centimeters deep. The insect pests observed during the conduct of the study were grasshopper, leafholder and bean aphids but in a tolerable level. The insect pests were repelled and prevented to invade again using tobacco and kakawate spray. Tobacco spray was applied 15 days and 50 days from planting while kakawate spray was applied 43 days from planting to prevent and repel insect pest.

So far, no disease was observed during the conduct of the study. But yellowing of the leaves at the lower part of the plant which are naturally occurring during maturity was observed. 
Harvesting was done when the leaves start to wither and turned to yellow, pods turned brownish and kernels loosen. It was done by loosening the soil with aid of trowel every hill and pulling the plants. The harvested pods from each plot were placed in the separate containers and were provided with markers to avoid misrepresentation of data. The newly harvested pods were dried under the sun for 2 days to prevent seed deterioration and fungi infection.

The data gathered and been recorded were the following: average number of pods per plant per plot, average weight of pods in gram per plant per plot, average number of seeds per plant per plot, total number of pods per plot, and total weight of pods in kilogram per plot. Analysis of Variance (ANOVA) for Two - Way classification without interaction was used in the study to determine if there was a significant difference in the yield performance of peanut as affected by different row and hill spacing. Duncan's' Multiple Range Test (DMRT) was also used in order to determine which of the different row and hill spacing of peanut gave a maximum yield.

\section{RESULTS AND DISCUSSION}

Average Number of Pods Per Plant Per Plot. Results revealed that the highest average number of pods (90.53) was observed in $T_{16}$ and lowest was observed in $T_{2}$ with an average number of 39.4. Result of the study revealed that 24 inches in row and 9 inches in hill is found effective and practical in peanut production (see Table 1)

Average Weight of Pods in Grams Per Plant Per Plot. Table 2 showed the average weight of pods per plant per plot (in grams). Results revealed that the highest average weight of pods $(258.86 \mathrm{~g})$ was seen in $\mathrm{T}_{16}$ and lowest was observed in $\mathrm{T}_{2}$ with an average weight of $129.66 \mathrm{~g}$. This revealed that 24 inches in row and 9 inches in hill is effective and useful in peanut production.

Average Number of Seeds Per Plant Per Plot. Results showed that the highest average number of seeds (132.53) was observed in $T_{16}$ and lowest was found in $T_{2}$ with an average number of 74.4. Result of the study revealed that 24 inches in row and 9 inches in hill is may be practical as well in terms of average number of seeds per plant per plot (see Table 3).

Total Number of Pods Per Plot. Table 4 showed the total number of pods per plot. Results revealed that the highest total number of pods per plot (4.176) was observed in $\mathrm{T}_{5}$ and lowest was seen in $\mathrm{T}_{2}$ and $\mathrm{T}_{7}$ with the total number of 3.120. Results revealed that 16 inches in row and six (6) inches in hill is found practical and applicable in peanut production.

Total Weight of Pods in Kilogram Per Plot. Table 5 showed the total weight of pods per plot. Results showed that the highest total weight of pods per plot $(15.98 \mathrm{~kg})$ was observed in $T_{5}$ and lowest was found in $T_{13}$ with the total number of $9.07 \mathrm{~kg}$. Result of the study revealed that 16 inches in row and 6 inches in hill is may be effective in peanut production. Result of the study showed that row and hill spacings are significant to improve yield and production of agronomical crops.

\section{Appendices}

\begin{tabular}{|l|l|l|l|l|l|l|}
\hline & $\mathrm{R}_{1}$ & $\mathrm{R}_{2}$ & $\mathrm{R}_{3}$ & $\mathrm{R}_{4}$ & Total & Mean \\
\hline $\mathrm{H}_{1}$ & 55.66 & 58.8 & 62 & 55.26 & 231.72 & \\
\hline $\mathrm{H}_{2}$ & 39.4 & 53.86 & 57.46 & 67.26 & 217.98 & \\
\hline $\mathrm{H}_{3}$ & 51.8 & 65.66 & 59.13 & 56.6 & 233.19 & \\
\hline $\mathrm{H}_{4}$ & 61.2 & 70 & 63.13 & 90.53 & 284.86 & \\
\hline Total & 208.06 & 248.32 & 241.72 & 269.65 & $967.75 \mathrm{~T}_{\mathrm{G}}$ & \\
\hline Mean & 52.01 & 62.08 & 60.43 & 67.41 & & $60.48 \mathrm{M}_{\mathrm{G}}$ \\
\hline
\end{tabular}

Table 1:- Average Number of Pods Per Plant Per Plot

\begin{tabular}{|c|c|c|c|c|c|c|}
\hline & $\mathrm{R}_{1}$ & $\mathrm{R}_{2}$ & $\mathrm{R}_{3}$ & $\mathrm{R}_{4}$ & Total & Mean \\
\hline $\mathrm{H}_{1}$ & \begin{tabular}{|l|l}
188.06 \\
\end{tabular} & \begin{tabular}{|l|}
222.26 \\
\end{tabular} & 202.86 & 189.06 & 802.24 & \\
\hline $\mathrm{H}_{2}$ & 129.66 & 185.13 & 221.06 & 197.8 & 733.65 & \\
\hline $\mathrm{H}_{3}$ & 190.73 & 243.13 & 181.93 & 167.66 & 783.45 & \\
\hline $\mathrm{H}_{4}$ & 190.73 & 224.4 & 205 & 258.86 & 878.99 & \\
\hline Total & 699.18 & 874.92 & 810.85 & 813.38 & $3198.33 \mathrm{~T}_{\mathrm{G}}$ & \\
\hline Mean & 174.79 & 218.73 & 202.71 & 203.34 & & $199.89 \mathrm{Mg}$ \\
\hline
\end{tabular}

Table 2:- Average Weight of Pods in Grams Per Plant Per Plot.

\begin{tabular}{|l|l|l|l|l|l|l|}
\hline & $\mathrm{R}_{1}$ & $\mathrm{R}_{2}$ & $\mathrm{R}_{3}$ & $\mathrm{R}_{4}$ & Total & Mean \\
\hline $\mathrm{H}_{1}$ & 100.53 & 104.33 & 117.66 & 106 & 428.52 & 107.13 \\
\hline $\mathrm{H}_{2}$ & 74.4 & 111.73 & 103.4 & 108.06 & 397.59 & 99.39 \\
\hline $\mathrm{H}_{3}$ & 91.33 & 115 & 112.26 & 102.4 & 420.99 & 105.24 \\
\hline $\mathrm{H}_{4}$ & 96.26 & 121.66 & 109.66 & 132.53 & 460.11 & 115.02 \\
\hline Total & 362.52 & 452.72 & 442.98 & 448.99 & $1707.21 \mathrm{~T}_{\mathrm{G}}$ & \\
\hline Mean & 90.63 & 113.18 & 110.74 & 112.24 & & $106.70 \mathrm{M}_{\mathrm{G}}$ \\
\hline
\end{tabular}

Table 3:- Average Number of Seeds Per Plant Per Plot.

\begin{tabular}{|c|c|c|c|c|c|c|}
\hline & $\mathrm{R}_{1}$ & $\mathrm{R}_{2}$ & $\mathrm{R}_{3}$ & $\mathrm{R}_{4}$ & Total & Mean \\
\hline $\mathrm{H}_{1}$ & 4,032 & 4,176 & 3,720 & 2,640 & 14,568 & 3,642 \\
\hline $\mathrm{H}_{2}$ & 3,120 & 3,180 & 3,850 & 3,680 & 13,830 & $3,457.5$ \\
\hline $\mathrm{H}_{3}$ & 3,264 & 3,120 & 3,360 & 3,792 & 13,536 & 3,384 \\
\hline $\mathrm{H}_{4}$ & 3,904 & 3,360 & 3,520 & 4,080 & 14,864 & 3,716 \\
\hline Total & 14,320 & 13,836 & 14,450 & 14,192 & $56,798 \mathrm{~T}_{\mathrm{G}}$ & \\
\hline Mean & 3,580 & 3,459 & $3,612.5$ & 3,548 & & $3549.87 \mathrm{Mg}$ \\
\hline
\end{tabular}

Table 4:- Total Number of Pods Per Plot.

\begin{tabular}{|l|l|l|l|l|l|l|}
\hline & $\mathrm{R}_{1}$ & $\mathrm{R}_{2}$ & $\mathrm{R}_{3}$ & $\mathrm{R}_{4}$ & Total & Mean \\
\hline $\mathrm{H}_{1}$ & 15 & 15.98 & 14.1 & 9.07 & 54.15 & 13.53 \\
\hline $\mathrm{H}_{2}$ & 10.32 & 11.1 & 14.36 & 14.15 & 49.93 & 12.48 \\
\hline $\mathrm{H}_{3}$ & 12.16 & 11.89 & 12.46 & 14.25 & 50.76 & 12.69 \\
\hline $\mathrm{H}_{4}$ & 14.56 & 12.46 & 12.89 & 15.5 & 55.41 & 13.85 \\
\hline Total & 52.04 & 51.43 & 53.81 & 52.97 & $210.25 \mathrm{~T}_{\mathrm{G}}$ & \\
\hline Mean & 13.01 & 12.85 & 13.45 & 13.24 & & $13.14 \mathrm{M}_{\mathrm{G}}$ \\
\hline
\end{tabular}

Table 5:- Total Weight of Pods in Kilogram Per Plot.

\section{CONCLUSION}

Based on the results of the study, the following conclusions were drawn:

There was no significant difference on the average number of pods per plant per plot, average weight of pods in gram per plant per plot, total number of pods per plot, and total weight of pods in kilogram per plot as affected by different row and hill spacings. However, the average number of seeds per plant per plot showed that there was a significant difference as affected by different row spacings. Nonetheless, there was no significant difference as affected by different hill spacings. 


\section{RECOMMENDATION}

Based on the foregoing findings and conclusions, the following are recommended:

The adoption of any of the combined treatments to obtain more number of pods per plant, to achieve heavier pods in grams, and to gain more number of peanut pods. However, in terms of number of seeds per plant, $R_{2}, R_{3}$, and $\mathrm{R}_{4}$ are recommended.

\section{REFERENCES}

[1]. Abu-Shakra, S; Akhar, M.; Bray, D. W. (1969) Influence of irrigation interval and plant density on alfalfa seed production. Agronomy journal 61: 562571.

[2]. Ali, A. A. G.; Fayed, E. A.; Basha, H. A. and Hassan, A. M. (1995b) Response of peanut to some agricultural practices III- Influence of sowing dates and the application of phosphorus and gypsum on quality of peanut plants. Zagazig J. Agric. Res. 22 (2): 349 .

[3]. Ali, A. A. G.; Fayed, E. A.; Basha, H. A. and Hassan, A. M. (1995a) Response of peanut to some agricultural practices II- Influence of sowing dates and the application of phosphorus and gypsum on yield and yield attributes of peanut plants. Zagazig J. Agric. Res. 22 (1): 49.

[4]. Askarian, M. (1993) Seed production studies in lucerne (Medicago sativa L.) cv. Grasslands Oranga. Unpubl. PhD thesis, Massey University, New Zealand.

[5]. Azab, M. A. (1993) Effect of rates, sowing dates and plant densities on groundnut. Al-Azhar J. Agric. Res. 17: 61 .

[6]. Donald, C.M. (1963) Competition Among Crops and Pasture Plants. Advences in Agronomy, 15: 17-27.

[7]. Dunbier, M. W.; Wynn-Williams, R. B.; Purves, R. G. (1983): Lucerne seed production in New Zealand: achievement and potential. Proceedings of the New Zealand Grassland Association 44: 30-35.

[8]. Egli, D.B. (1988) Plant Density and Soybean Yield. Crop Science, 28:977-980

[9]. El-far, I. A. and Ramadan, B. R. (2000) Response of yield, yield components and seed quality of peanut (Arachis hypogaea L.) to plant density and fertilization in sandy calcareous soil. Proc. 9th Conf. Agron., Minufiya Univ. (1-2): 453.

[10]. El-Seesy, M. A. and Ashoub, A. H. (1994) Productivity of groundnut (Arachis hypogaea L.) as affected by different population and nitrogen levels. Annals of Agric. Sci. Moshtohor 32 (3): 1199.

[11]. Goplen, B. P. (1972) Management of alfalfa fields for seed production. Proceedings of the Leafcutter Bees and Alfalfa Seed Production Conference . Saskatoon. 8 p.
[12]. Gulluoglu, L. (2011). Effects of Regulator Applications on Pod Yield and Some Agronomic Characters of Peanut in Mediterranean Region. Turkish Journal of Field Crops. 16(2):210-214

[13]. Gulluoglu, L., H. Bakal, B. Onat, C. Kurt, and H. Arioglu. (2016a) The Effect of Harvesting Dates on Yield and Some Agronomic and Quality Characteristics of Peanut Grown in Mediterranean Region (Turkey) Turkish Journal of Field Crops. 21(2): 224-232 (DOI:10.17557/tifc.20186)

[14]. Kasai, F. S.; Athayde, M. L. F.; Godoy, I. D. and IJ, D. G. (1998) Peanut oil and protein yield in function of phosphate fertilization and harvest time. Bragantia 57 (1): 163.

[15]. Kowithayakorn, L.; Hill, M. J. (1982) A study of herbage and seed production of lucerne \{Medicago sativa L.) under different plant spacing and cutting treatments in the seeding year. Seed science and technology 10: 3-12.

[16]. Lovato, A.; Montanari, M. (1987) Influence of row spacing and sowing rates on lucerne (Medicago sativa L.) seed production. Journal of applied seed production 5: 69.

[17]. Madkour, M.A., S.I. El- Mohandes, A.M.El-wakil (1992) Effect of Row-Spacing, Phosphorus, Potassium and Born Application on Some Peanut Cultivars. Egypt J. Agron., 17:127-140.

[18]. Palmer, T. P.; Donovan, B. J. (1980) Seed production of new cultivars of lucerne. Pp. 87-91 in: Herbage seed production, Grassland Research and Practice Series 1, Lancashire, J. A. ed.

[19]. Papastylianou, I.. (1995) Spacing of Peanut Plants (Arachis hypogaea L.) Under Irrigation. Eur. J. Agron., 4: 101107.

[20]. Pedersen, M. W.; Nye, W. P. (1962) Additional factors associated with seed yield. In: Alfalfa seed production studies. Utah Agricultural Experimental Station bulletin 436. 22 p.

[21]. Rasekh, H., J. Asghari, M.N. Safarzadeh Wishkai, S.L. Massoumi and R. Zakerinejad. (2010) Effect of Planting Pattern and Plant Density on Physiological Characteristics and Yield of Peanut (Arachis hypogeal L.) in Iran. Research J. of Biological Sciences., 5(8):542-547.

[22]. Rinjumoni, D.; Gogoi, P. K.; Baroova, S. R.; Deka, N. C. and Dutta, R. (2000) Effect of sowing dates and mulching on rabi groundnut (Arachis hypogaea L.) under rainfed conditions. Annals Agric. Res. 21 (4): 557.

[23]. Rossetto, C. A. V.; Nakagawa, J. and Rosolem, C. A. (1998) Effect of harvesting date and liming on yield of groundnuts cv. Botutatu. Pesquisa Agropecuaria Brasileira 33 (5): 665.

[24]. Shams El-din, G. M., and Ali, E. A. (1996) Upgrading productivity of two peanut (Arachis hypogaea L.) varieties through applying optimum plant spacing and micronutrients application. Arab Univ. J. Agric. Sci., Ain shams Univ., Cairo 4 (1-2): 53. 
[25]. Silvertooth, J.C, K.L. Edmisten, W.H. McCarty. (1999) Production Practices. In: Cotton Origin, History, Technology and Production, eds C. W. Smith and J. T. Cothren, pp. 451-488. New York: John Wiley\&Sons

[26]. Sungwoo, L.; Changhwan, P. and Chulwha, K. (1999) Changes in oil, tannin, total sugar contents and yield after flowering in peanut. Korean J. Crop Sci. 44 (2): 159.

[27]. Wynn-Williams, R. B.; Palmer, T. P. (1974) Seeding rates, row spacing and lucerne (Medicago sativa L.) cv. Saranac seed production. Proceedings of the Agronomy Society of New Zealand 4: 63-66. 